\title{
PERAN KETIDAKNYAMANAN KERJA TERHADAP INTENSI PINDAH KERJA
}

\author{
Ranisya Fitta ${ }^{1}$, Fransisca Iriani Roesmala Dewi ${ }^{2}$, Rita Markus Idulfilastri ${ }^{3}$ \\ ${ }^{1}$ Program Studi Magister Psikologi, Universitas Tarumanagara, Jakarta \\ Email: ranisya.707172001@stu.untar.ac.id \\ ${ }^{2}$ Fakultas Psikologi, Universitas Tarumanagara, Jakarta \\ Email:fransiscar@fpsi.untar.ac.id \\ ${ }^{3}$ Fakultas Psikologi, Universitas Tarumanagara, Jakarta \\ Email: ritamarkus@fpsi.untar.ac.id
}

Masuk : 08-08-2020, revisi: 23-10-2020, diterima untuk diterbitkan : 31-10-2020

\begin{abstract}
$P T X$ is a startup company engaged in financial technology, experiencing an increased in the number of turnover. Turnover has a negative impact on the company. Company will lack human resources and need time recruiting and training new employees. Turnover intention is an accurate predictor of the number of turnover. An organization can't eliminate the intention of employee turnover, but can reduce the level of intention. One of the factor that cause frequent employee desires to leave the company are employee insecurities at job. T test results of this study indicate that the standard value of the coefficient job insecurity is 0.189 with a significance level of 0,000. Based on the results can be concluded that job insecurity has a significant and positive effect of turnover intention.
\end{abstract}

Keywords: startup company, turnover intention, job insecurity, organizational commitment

\section{ABSTRAK}

PT. X adalah perusahaan rintisan yang bergerak di bidang financial technology, mengalami peningkatan angka pindah kerja. Pindah kerja memberikan dampak yang negatif bagi perusahaan. Perusahaan akan kekurangan sumber daya manusia dan membutuhkan waktu untuk merekrut serta melatih karyawan baru. Intensi pindah kerja adalah peramal yang akurat terhadap angka pindah kerja. Suatu organisasi tidak dapat menghilangkan intensi pindah kerja karyawan, namun dapat mengurangi tingkat intensi tersebut. Salah satu faktor yang menyebabkan sering terjadinya keinginan karyawan untuk keluar dari perusahaan tempat bekerja adalah perasaan tidak nyaman karyawan pada pekerjaannya. Hasil Uji T pada penelitian ini menunjukkan bahwa nilai standar koefisien yang diperoleh pada ketidakamanan kerja sebesar 0.189 dengan tingkat signifikansi 0.000. Berdasarkan hasil tersebut dapat disimpulkan bahwa ketidaknyamanan kerja berpengaruh signifikan dan positif terhadap intensi pindah kerja.

Kata Kunci: perusahaan rintisan, intensi pindah kerja, ketidaknyamanan kerja, komitmen organisasi

\section{PENDAHULUAN}

\section{Latar Belakang}

Perkembangan internet menandakan telah berjalannya globalisasi. Setiap individu dalam dunia maya memiliki hak dan kemampuan untuk berinteraksi dengan individu lain tanpa batasan yang dapat menghalanginya. Globalisasi menghubungkan seluruh komunitas informasi dan telekomunikasi (digital), sehingga berdampak bagi seluruh sektor perekonomian. Sektor bisnis merupakan sektor yang paling mendapatkan dampak dari perkembangan teknologi informasi dan telekomunikasi serta paling cepat bertumbuh (Ersafitri, 2015). Pertumbuhan industri digital ditandai dengan munculnya perusahaan rintisan digital yang dirintis oleh generasi muda (Arjanti \& Mosal, 2012). Bisnis atau usaha rintisan sering dikaitkan dengan teknologi informatika seperti website, ataupun internet (Rahayu, 2018). Indonesia tercatat sebagai negara ke-4 di dunia dengan jumlah perusahaan rintisan terbanyak yaitu sebesar 1.559 perusahaan (Startupranking.com, 2018, chap. country).

Salah satu daya tarik untuk menekuni dunia perusahaan rintisan adalah berhubungan langsung dengan dunia digital. Dunia digital menjadi lahan perkembangan perusahaan rintisan dan 
memperbolehkan karyawan bergaya kasual. Gaya kasual memberikan kebebasan kepada karyawan saat bekerja. Beberapa gaya kasual itu antara lain: kebebasan berpakaian, fleksibilitas jam kerja dan lokasi kerja (bekerja dari rumah atau bekerja di kantor). Faktor ini menjadi salah satu daya tarik bagi lulusan baru dan tenaga kerja muda bekerja di perusahaan rintisan. Faktor lain yang dituntut adalah daya tahan, kecerdasan dan kemampuan beradaptasi (Rahayu, 2018). Di sisi lainnya, tantangan yang akan dihadapi karyawan di perusahaan rintisan, antara lain: gaji dan tunjangan kerja yang belum memadai, struktur organisasi yang belum terbentuk sehingga karyawan mengerjakan beberapa pekerjaan (multitasking), ketidakstabilan pendapatan perusahaan serta kultur kerja yang terus berkembang (Rahayu, 2018). Hal lain yang menjadi perbedaan perusahaan rintisan dengan perusahaan konvensional adalah dinamika kerja. Perusahaan rintisan sangat dinamis dan penuh ketidakpastian (Bussgang, 2017). Pada konteks perusahaan rintisan yang berbasis teknologi, tuntutan pekerjaan sejalan dengan perkembangan perusahaan rintisan dari yang semula membangun sistem sampai melakukan pengembangan produk secara berkelanjutan (Areitio, 2019).

PT. X adalah perusahaan rintisan yang bergerak di bidang financial technology, mengalami peningkatan angka pindah kerja terhitung sejak 3 tahun terakhir. Angka pindah kerja tersebut terus meningkat dari tahun ke tahun. Berdasarkan data yang diperoleh dari PT. X ketika exit interview, terdapat beberapa faktor alasan karyawan memutuskan untuk pindah kerja. Alasan karyawan untuk pindah kerja, antara lain: (a) sebesar 54\% mendapatkan tawaran dari perusahaan rintisan lain, (b) sebesar 28\% kembali ke perusahaan lama, dan (c) sebesar $18 \%$ beralasan personal matters. Pada tahun 2017, mayoritas alasan karyawan memutuskan untuk pindah kerja adalah merasa PT. X dinilai belum stabil dan belum adanya benefit yang layak mereka dapatkan. Pada tahun 2018, mayoritas alasan karyawan memutuskan untuk pindah kerja adalah tekanan dan target yang harus mereka capai semakin tinggi sehingga beberapa karyawan tidak kuat dan memutuskan untuk keluar dari organisasi.

Pindah kerja memberikan dampak yang negatif bagi perusahaan. Ketika angka pindah kerja pada perusahaan meningkat, maka perusahaan harus mengeluarkan biaya lebih untuk proses perekrutan dan pelatihan karyawan baru. Untuk mengetahui tingkat pindah kerja yang sebenarnya (actual turnover) tidak dapat dilakukan dengan mudah, sehingga diperlukan cara yang dapat mengidentifikasi pindah kerja lebih awal yaitu melalui intensi pindah kerja (Kim, 2008). Al Battat, Som, dan Helahat (2013) dalam penelitiannya menyatakan bahwa intensi pindah kerja adalah peramal yang akurat terhadap angka pindah kerja.

Suatu organisasi tidak dapat menghilangkan intensi pindah kerja karyawan, namun dapat mengurangi tingkat intensi tersebut (Kim, 2008). Intensi pindah kerja dapat berupa rencana dan keinginan untuk meninggalkan organisasi (Jennings, 2014). Intensi pindah kerja yang tinggi terjadi pada suatu organisasi bukanlah suatu kebetulan, tetapi disebabkan oleh beberapa faktor pendukung. Salah satu faktor yang menyebabkan sering terjadinya keinginan karyawan untuk keluar dari perusahaan tempat bekerja yaitu perasaan tidak nyaman karyawan pada pekerjaannya (Kim, 2008).

Ketidaknyamanan kerja adalah kekhawatiran yang bersifat subjektif mengenai kemungkinan kehilangan karirnya di masa mendatang (Alghamdi, 2018). Ketidaknyamanan kerja sebagai pengalaman subjektif yang dihasilkan dari persepsi dan interpretasi seseorang terhadap lingkungan kerja yang aktual. Hal tersebut berarti situasi lingkungan yang serupa dapat menghasilkan respon sikap yang berbeda pada tiap-tiap karyawan. Kemudian, kekhawatiran mengenai masa depan adalah akar dari pengalaman ketidaknyamanan kerja. Pengalaman tersebut 
meliputi peluang seseorang untuk kehilangan pekerjaan maupun kekhawatiran yang berhubungan dengan ancaman yang dirasakan (Elst, Witte, \& Cuyper, 2014).

Karyawan yang merasa tidak nyaman dalam pekerjaannya, akan mengalami hambatan dalam menyelesaikan pekerjaan. Karyawan mengalami penurunan semangat kerja, kurang motivasi untuk menyelesaikan pekerjaan sesuai dengan waktu yang telah ditentukan, lebih sering melanggar aturan yang telah ditetapkan (Mauno, Cuyper, Tolvanen, Kinnunen, \& Maikangas, 2014). Selain itu, karyawan akan mengalami rasa tidak nyaman yang meningkat karena ketidakstabilan status kepegawaian dan tingkat pendapatan yang tidak bisa diramalkan, yang berakibat intensi pindah kerja akan cenderung meningkat (Lee \& Jeong, 2017). Karyawan yang merasa sudah tidak nyaman terhadap pekerjaannya sangat rentan berpikir untuk meninggalkan organisasi (Kim, 2008). Lee dan Joeng (2017), dalam penelitiannya menyatakan bahwa ketidaknyamanan kerja berperan terhadap intensi pindah kerja. Hal tersebut sesuai dengan penelitian yang dilakukan oleh Adesubomi (2018) serta penelitian yang dilakukan oleh Alghamdi (2018).

Berdasarkan uraian tersebut, penulis tertarik untuk menguji peran ketidaknyamanan kerja dan komitmen organisasi terhadap intensi pindah kerja dengan partisipan karyawan perusahaan rintisan. Sejauh pengetahuan yang penulis miliki, di Indonesia belum banyak penelitian tentang karyawan perusahaan rintisan. Rumusan masalah dalam penelitian ini akan menguji apakah terdapat peran ketidaknyamanan kerja terhadap intensi pindah kerja.

\section{METODE PENELITIAN}

\section{Partisipan dan Prosedur Penelitian}

Metode penelitian yang digunakan adalah penelitian kuantitatif korelasional, non-eksperimental. Pada penelitian ini teknik pengambilan sampel dilakukan secara convenience sampling. Partisipan penelitian berasal dari satu perusahaan rintisan yang bergerak di bidang financial technology dengan level staff hingga level manager. Kriteria yang harus dipenuhi oleh partisipan adalah telah bekerja selama minimal 6 bulan sebagai karyawan perusahaan rintisan. Partisipan penelitian tidak dibatasi oleh jenis kelamin dan usia.

Teknik pengumpulan data menggunakan kuesioner. Peneliti memberikan kuesioner secara langsung kepada partisipan yang memenuhi kriteria yang telah ditentukan. Selain pembagian kuesioner secara langsung, peneliti juga memberikan alternatif pengisian kuesioner lain via online dengan menggunakan aplikasi Google Forms yang disebarkan melalui aplikasi slack.

\section{Pengukuran}

Penelitian ini menggunakan alat ukur Turnover Intention Scale (TIS) yang dikembangkan oleh Mobley, W. H., Horner, S. O., dan Hollingsworth, A. T. pada tahun 1987. Alat ukur ini telah digunakan oleh Agustina, T., dan Sjabadhyni, B. (2014). Pada alat ukur TIS terdiri dari 3 butir pertanyaan dan keseluruhan butir adalah butir positif. Pada penelitian ini, menggunakan skala likert 1-6. Setelah dilakukan pengujian reliabiltas pada alat ukur intensi pindah kerja, tidak ada butir yang dihapus. Nilai cronbach's alpha yang dihasilkan sebesar 0.975 maka alat ukur ini reliabel.

Penelitian ini menggunakan alat ukur Job Insecurity Questionnaire (JIQ) yang dikembangkan oleh De Witte pada tahun 2000. Alat ukur ini telah digunakan oleh Pillay (2006). Pada alat ukur JIQ terdiri dari 11 butir pertanyaan dengan butir positif pada butir 5,6,7,8,9,10,11 dan butir negatif pada butir 1,2,3,4. Pada penelitian ini, menggunakan skala likert 1-5. Setelah dilakukan 
pengujian reliabiltas pada alat ukur ketidaknyamanan kerja, tidak ada butir yang dihapus. Nilai cronbach's alpha yang dihasilkan sebesar 0.967 maka alat ukur ini reliabel.

\section{HASIL DAN PEMBAHASAN}

\section{Hasil}

Pada uji hipotesis, penelitian dilakukan untuk menguji peran antara variabel independen yaitu ketidaknyamanan kerja dan variabel dependen yaitu intensi pindah kerja. Penulis melakukan pengujian hipotesis dengan melakukan regresi linear sederhana dengan bantuan aplikasi SPSS Statistics 25.

Tabel 1. Hasil Uji Regresi Ketidaknyamanan Kerja terhadap Intensi Pindah Kerja

\begin{tabular}{lcccc}
\hline Model & $\mathrm{R}$ & R Square & $\begin{array}{c}\text { Adjusted R } \\
\text { Square }\end{array}$ & $\begin{array}{c}\text { Std. Error of } \\
\text { the Estimate }\end{array}$ \\
\hline 1 & 0.504 & 0.255 & 0.242 & 1.3041 \\
\hline
\end{tabular}

Pada perhitungan nilai regresi diperoleh nilai $\mathrm{R}$ Square sebesar 0.255 , sedangkan adjusted $R$ Square sebesar 0.242 yang diperoleh dari hasil kuadrat dari $R$ Square $\left(0.255^{2}\right)$. Hal tersebut menunjukkan bahwa ketidaknyamanan kerja berperan sebesar $25.5 \%$ terhadap intensi pindah kerja sedangkan sisanya $74.5 \%(100 \%-25.5 \%)$ dipengaruhi oleh faktor lain.

Tabel 2. Hasil Uji T Ketidaknyamanan Kerja terhadap Intensi Pindah Kerja

\begin{tabular}{|c|c|c|c|c|c|c|}
\hline \multirow[t]{2}{*}{ Model } & & \multicolumn{2}{|c|}{$\begin{array}{l}\text { Unstandardized } \\
\text { Coefficients }\end{array}$} & \multirow{2}{*}{$\begin{array}{c}\begin{array}{c}\text { Standardized } \\
\text { Coefficients }\end{array} \\
\text { Beta }\end{array}$} & \multirow[t]{2}{*}{$\mathrm{t}$} & \multirow[t]{2}{*}{ Sig. } \\
\hline & & $\mathrm{B}$ & $\begin{array}{l}\text { Std. } \\
\text { Error }\end{array}$ & & & \\
\hline & (Constant) & 0.824 & 0.820 & & 1.0005 & 0.319 \\
\hline 1 & $\begin{array}{c}\text { Ketidaknyamanan } \\
\text { Kerja }\end{array}$ & 0.845 & 0.190 & 0.504 & 4.450 & 0.000 \\
\hline
\end{tabular}

Nilai standar koefisien yang diperoleh pada ketidaknyamanan kerja sebesar 0.504 dengan tingkat signifikansi 0.000. Berdasarkan hasil tersebut dapat disimpulkan bahwa ketidaknyamanan kerja berperan signifikan dan positif terhadap intensi pindah kerja.

\section{Pembahasan}

Rumusan masalah dalam penelitian ini menguji apakah terdapat peran ketidaknyamanan kerja terhadap intensi pindah kerja. Setelah dilakukan pengujian, hasil penelitian ini menunjukkan adanya peran antara ketidaknyamanan kerja dan komitmen organisasi terhadap intensi pindah kerja. Ketidaknyamanan kerja memiliki peran sebesar $25.5 \%$ terhadap intensi pindah kerja. Hal tersebut sesuai dengan penelitian yang dilakukan Lee dan Joeng (2017), Adesubomi (2018) dan Alghamdi (2018), bahwa terdapat peran antara ketidaknyamanan kerja terhadap intensi pindah kerja.

Penelitian ini terbatas pada satu perusahaan rintisan dan jenis bisnis perusahaan rintisan. Mengingat banyaknya perusahaan rintisan dan jenisnya, akan lebih baik jika partisipan diambil dari beberapa jenis perusahaan rintisan yang berbeda. Selain itu, penelitian ini tidak dapat digeneralisasikan untuk keseluruhan perusahaan rintisan mengingat karena partisipan yang terbatas. 


\section{KESIMPULAN DAN SARAN}

Penelitian ini memiliki tujuan untuk mengetahui peran ketidaknyamanan kerja terhadap intensi pindah kerja. Pada penelitian ini, terdapat 60 partisipan penelitian yang bekerja di perusahaan rintisan yang bergerak di bidang financial technology. Penelitian dilakukan dengan desain penelitian kuantitatif korelasional, non-eksperimental. Pada penelitian ini, ketidaknyamanan kerja memiliki peran sebesar $25.5 \%$ terhadap intensi pindah kerja. Berdasarkan hasil penelitian yang dilakukan oleh penulis, dapat disimpulkan bahwa terdapat peran ketidaknyamanan kerja terhadap intensi pindah kerja. Berdasarkan uraian di atas, dapat disimpulkan bahwa hipotesis diterima.

Penelitian ini memiliki beberapa keterbatasan yaitu pertama, penelitian ini hanya dilakukan pada satu perusahaan rintisan bidang financial technology. Jika partisipan penelitian berasal dari beberapa perusahaan rintisan maka hasil dapat lebih bervariasi. Kedua, penelitian ini hanya melihat peran antara ketidaknyamanan kerja terhadap intensi pindah kerja. Pada penelitian selanjutnya dapat memilih variabel independen yang lain atau variabel yang dapat berperan sebagai moderator atau mediator.

\section{Ucapan Terima Kasih (Acknowledgement)}

Kami mengucapkan terima kasih dan penghargaan kepada PT. X serta seluruh partisipan yang telah berkontribusi dalam penelitian ini.

\section{REFERENSI}

Adesubomi, A.B. (2018). Impact of employees' job insecurity and employee turnover on organisational performance in private and public sector organisations. Studies in Business and Economics, 13(2), 5-9. Doi: 10.2478/sbe-2018-0016

Agustina, T., \& Sjabadhyni, B. (2014). Hubungan antara sikap terhadap uang dan turnover intention pada karyawan. Universitas Indonesia. https://www.google.com/url?sa=t\&rct=j\&q=\&esrc=s\&source=web\&cd=\&ved=2ahUKE wjJquSQsuvtAhWO4XMBHX0QA3wQFjAAegQIAxAC\&url=http\%3A\%2F\%2Flib.ui.a c.id\%2Fnaskahringkas\%2F2016-12\%2FS58631Tri\%2520Agustina\&usg=AOvVaw1Yj_FSCi6FLBNOcL8-CP5d

Al Battat, A. R., Som, A. P. M., \& Helahat, A. S. (2013). Overcoming staff turnover in the hospitality industry using Mobley's model. Journal of Learning \& Development, 3(6), 64-71. Doi: https://doi.org/10.5296/ijld.v3i6.4844

Alghamdi, F. (2018). Job insecurity, organizational commitment, financial responsibility, and turnover intention, a test of three-way interaction. International Business Research, 11(6), 213-225. Doi:10.5539/ibr.v11n6p213

Areitio, A. (2019, Januari 16). From idea to scaleup: Startup stages, understanding the milestones at every Stage Toward Success. https://medium.com/theventurecity/from idea-to-scaleup-startup-stages-a268799325d7

Arjanti, R. A., \& Mosal, R. L. (2012). Start-up, Indonesia! inspirasi dan pelajaran dari para pendiri binsis digital. Jakarta: Kompas.

Bussgang, J. J. (2017, November 01). Are you suited for a start-up?. https://store.hbr.org/product/are-you-suited-for-a-start-up/r1706m?sku=R1706M-PDFENG

Elst, V. T., Witte, H. D., \& Cuyper, N D. (2014). The job insecurity scale: A psychometric evaluation across five European countries. European Journal of Work and Organizational Psychology, 23(3), 364-380. https://doi.org/10.1080/1359432X.2012.745989 
Ersafitri, O. (2015). Pengaruh relationship cultivation sebagai strategi public relations terhadap brand image (Studi pada facebook fan page bunda konicare). Jurnal Ilmiah Universitas Bakrie, 3(3). https://www.neliti.com/publications/253753/pengaruh-relationshipcultivation-sebagai-strategi-public-relations-terhadap-bra\#cite

Jennings, L. A. (2014). Comparison study: Office-based and telecommuting call center employee's level of job satisfaction and turnover intent. Dissertation Abstracts International Section A: Humanities And Social Sciences.

Kim, K. I. (2008). "The effects of burnout on turnover intention: The moderating effect on communication satisfaction [In Korean] (Unpublished master's thesis)". Kyungpook National University, South Korea.

Lee, S. H., \& Jeong, D. Y. (2017). Job insecurity and turnover intention: Organizational commitment as mediator. Social Behavior and Personality, 45(4), 529-536. Doi: https://doi.org/10.2224/sbp.5865

Mauno, S., De Cuyper, N., Tolvanen, A., Kinnunen, U., \& Mäkikangas, A. (2014). Occupational well-being as a mediator between job insecurity and turnover intention: Findings at the individual and work department levels. European Journal of Work and Organizational Psychology, 23(3), 381-393. https://doi.org/10.1080/1359432X.2012.752896

Pillay, S. (2006). The relationship between job insecurity, job satisfaction and organizational commitment in a telecomunication organization. University of KwaZulu, South Africa. researchspace.ukzn.ac.za/bitstream/handle/10413/1394/Pillay_S_2006.pdf?isAllowed=y \&sequence $=1$

Rahayu, N. (2018, April 06), 7 Karakteristik Startup. Di unduh dari https://www.wartaekonomi.co.id/read176487/7-karakteristik-startup.html.

Start Up Ranking. (2018). Startups ranking per country. Di unduh dari https://www.startupranking.com/countries 